\title{
RURAL RESIDENTS SATISFACTION AND INFLUENCING FACTORS IN THE SUPPLY OF PUBLIC GOODS IN CHINA
}

\author{
Yaobo Shi ${ }^{1}$ and Xinxin Zhao ${ }^{2}$ \\ ${ }^{1}$ School of Economics and Management, Xi'an University of Technology, Shaanxi, China. \\ Email: shiyaobo@xaut.edu.cn \\ ${ }^{2}$ School of Economics and Finance, Xi'an Jiaotong University, Shaanxi, China. \\ Email: xinxin.zhao@gmail.com
}

\begin{abstract}
The satisfaction of farmers with the supply of rural public goods is an important indicator of the effectiveness of rural public goods investment. Using cross-sectional data on 400 farmers in five counties of China's Shaanxi province, this study adopts ordinal logit and probit models to investigate rural residents' satisfaction and the influencing factors in the supply of public goods. The empirical results indicate that the income of farmers has a significantly negative impact on their satisfaction, farmers who were consulted in the process of public goods supply have higher satisfaction levels than farmers who were not, and farmers who profited from the supply of public goods are more satisfied than those who did not. Additionally, other factors have a significant impact on the satisfaction of certain public products. For example, the older the respondents, the higher their satisfaction with medical hygiene service and higher education levels among the respondents reduce their satisfaction with compulsory education. Our empirical results provide a relevant reference for government departments in China.
\end{abstract}

Keywords: Ordinal logit model; Ordinal probit model; Public goods supply; China. JEL Classifications: H31; H41; I30.

Article history:

Received : July 10, 2018

Revised : : September 7, 2018

Accepted : December 17, 2018

Available online : January 31, 2019

https://doi.org/10.21098/bemp.v0i0.943 


\section{INTRODUCTION}

Since a long time, public goods have been considered a prerequisite for economic growth and social development. In particular, the role of rural public goods cannot be underestimated in the development of rural economies. Compared to urban areas, rural areas are dependent on public goods due to the vastness of their territory, low levels of economic development, and weak self-development. Experience in developed countries shows that the supply of rural public goods plays an important role in transforming traditional agriculture, upgrading rural industries, introducing modern civilization to rural areas, and improving farmers' living conditions (Ju and Pang, 2005).

Farmers are the most important users of rural public goods. Therefore, they have the right to express their demands regarding rural public goods and their satisfaction with the supply of rural public goods is an important indicator of the effectiveness of rural public goods investment (Zhao and Jiang, 2007). From the perspective of farmers, investments in rural public goods that they need most are the most effective ( $\mathrm{Li}, 2008)$. However, China's rural public goods supply mechanism is a top-down public product investment decision making mechanism (Gu and Wang, 2005). In the process of supplying public goods, China's government has always played an important role and the consumers of rural public goodsthe farmers-have been in a position of passive acceptance (Zeng, 2008). This has caused the rural populations' demands and the government's supply to be unequal in China, resulting in wasted resources. Therefore, a full consideration of farmer satisfaction with rural public goods and influencing factors has important theoretical and practical significance in improving the supply mode of public goods and improving the efficiency of public goods investment.

Research on the factors influencing rural residents' satisfaction with public goods investment mainly considers two aspects. On the one hand, some studies use qualitative research methods to focus on the factors affecting the satisfaction of rural residents in the investment of specific rural public goods (Zheng, 2011). On the other hand, quantitative methods are adopted, focusing on the factors affecting the overall satisfaction of rural residents with the supply of public goods (Zhu and Tang, 2010; Zhu et al., 2011; Xiao, 2012; Li et al., 2014). However, previous studies do not quantitatively analyze the factors affecting farmers' satisfaction with the supply of specific public goods. Additionally, the previous literature on satisfaction with the supply of rural public goods is based on a binary model, which cannot reflect the degrees of farmer satisfaction.

Our paper contributes to the literature in several aspects. First, it adopts the sample survey data of 400 rural households' satisfaction with the rural public goods supply in five counties of Shaanxi province in China and uses ordinal logit and probit regression models to empirically analyze satisfaction with the supply of rural public goods and its influencing factors. Second, we divide the supply of public goods into the following categories: farmland water conservancy facilities, road construction, agricultural services, medical hygiene services, compulsory education, drinking water facilities, Information and Communications Technology (ICT), and garbage disposal. We then investigate farmers' satisfaction with each category of public goods, respectively. Third, we define the concept of rural households' satisfaction as an orderly latent variable. 
This paper is organized as follows. Section II briefly reviews of the evaluation of satisfaction with the supply of rural public goods. Section III presents the data and methodology. Section IV discusses the results of the empirical analysis. Section $\mathrm{V}$ draws conclusions and notes the study's limitations.

\section{LITERATURE REVIEW}

Satisfaction is a kind of psychological state experienced by the customer that was first proposed by Cardozo (1965), who argues that customer satisfaction with a product is influenced by the effort spent on its purchase and the customer's expectations of it. Fornell (1992) demonstrates that customer satisfaction is the overall judgment of a product or service after its purchase and indicates that the customer expects satisfaction is positive. After improving the indicators of customer satisfaction for the United States, Hsu (2008) uses partial least squares to evaluate online customer satisfaction and analyzes its main influencing factors.

In recent years, customer satisfaction theory has been used increasingly widely in the research field of rural public goods and services. The main consumers of rural public goods are farmers; so, customer satisfaction can be called farmers' satisfaction. Li et al. (2006) uses the data from two sample surveys in 2003 and 2005 to study the satisfaction of village-level public goods investment. Focusing on the six public goods of roads, schools, irrigation water, drinking water, clinics, and household waste, the authors find that farmers are the least satisfied with roads and irrigation. Fan et al. (2008) investigate the satisfaction of 245 rural households in the three provinces of Shandong, Hebei, and Jiangsu for 10 public goods regarding production, living, and welfare protection, and find that farmers are satisfied with public health, epidemic prevention, and new rural cooperative medical care. Wang (2008) conducted a survey of three counties in Shandong province and finds that farmers have higher levels of satisfaction with road construction, the rural power grid, compulsory education, and water conservancy facilities and lower levels of satisfaction with cultural and entertainment facilities. Li and Zeng (2008) use survey data to evaluate the satisfaction of 126 township farmers with the supply of rural public goods in Hunan Province. They use a probit regression model to empirically analyze satisfaction with rural public goods and its influencing factors and find that farmers' satisfaction appears to be mainly affected by factors such as their level of education, medical accessibility, income level, and distance to township government offices. Based on data from Zhejiang Province, Wang and Jiang (2009) use principal component analysis and find that high levels of satisfaction with the rural infrastructure but public investment in health care, education, and old age security need to be strengthened. Using the survey data of 556 rural households in Shaanxi province, Wang and Zhu (2012) use a fuzzy comprehensive evaluation method to empirically analyze the effect of the supply of rural public goods and find that farmers are more satisfied with productive public goods. Using survey data from three regions of Hubei province, Xiao (2012) finds that social security, traffic conditions, housing status, education investment, and medical services all affect farmers' satisfaction with public investment. Age, education level, and income sources have a significant impact on satisfaction. The author also finds low farmer satisfaction with the supply of rural public goods, 
lack of investment in education being the main constraint. Xu (2012) selects 21 counties in Jiangxi and uses an optimized direct method sorting selection model to empirically study satisfaction with rural public goods and its influencing factors and finds farmers' age, education of the farmer, per capita income, roads, water conservancy, garbage disposal, and so forth, have a great impact on satisfaction.

In addition, studies have been conducted on resident satisfaction with certain types of public investments. Wang and Jiang (2010) conducted a study on the satisfaction of residents' medical services and find that the rural residents' age, region, occupation, and family income directly affect their satisfaction with medical services. Their degree of education, type of illness, and mode of diagnosis and treatment indirectly affect satisfaction. Xu et al. (2014) analyze satisfaction with and the influencing factors in the supply of farmers' irrigation facilities in hilly areas by using cross-sectional survey data from Sichuan province in China in 2014. The regression results show that the farmers' satisfaction is low and that, among other factors, their gender, party membership, receipt of benefits, and family structure affect this satisfaction.

The main limitations of current research are as follows. First, previous studies only analyze farmers' satisfaction with public goods overall rather than with different individual public goods. Second, some studies only conducted resident satisfaction surveys regarding certain parts of public investments and did not investigate satisfaction with other public goods. Third, few of studies use ordered regression methods such as ordinal logit and probit estimations to investigate the influencing factors of farmer satisfaction. Therefore, this paper studies satisfaction with Shaanxi's public investment and influencing factors from the perspective of residents.

\section{DATA AND METHODOLOGY}

A. Data

Our data are from a random sampling of surveys directed by the Center for Chinese Agricultural Policy of the Chinese Academy of Sciences and Northwestern University in 2012. These national survey activities collected representative data from 36 counties in six Chinese provinces, each province, county, and township having been randomly selected. We extracted village-level data for Shaanxi province from the national survey data. ${ }^{3}$ We chose Shaanxi as the sample area because it is in western China, which has harsh natural and geographical conditions and weak economic development, especially in rural areas. Therefore, compared with other regions in China, farmers in the western region have an even greater need for public goods to protect their production and standards of living.

3 The five sample counties in Shaanxi province are Huangling, Ansai, Shangnan, Lueyang, and Binxian counties. A total of 400 households in 20 villages in 10 towns in five counties were selected. 


\section{A1. Dependent Variables}

This study aims to investigate farmers' satisfaction with the supply of each of eight types of public goods and influencing factors. Therefore, we choose farmers' levels of satisfaction with these eight important types of public goods as the dependent variables. The eight categories include farmland water conservancy facilities, roads, agricultural services, medical hygiene services, compulsory education, drinking water facilities, ICT, and garbage disposal. We define rural households' satisfaction with specific public goods supply as an orderly latent variable $(1=$ very not satisfied, 2 = not satisfied, 3 = indifferent, $4=$ satisfied, $5=$ very satisfied).

\section{A2. Explanatory Variables}

The correct choice of variables is important in econometric models. We select the following factors that can affect farmers' satisfaction with rural public goods.

(1) Respondent's gender. Farmers of different gender could have different needs in terms of public goods, which could affect their satisfaction.

(2) Respondent's age. Compared with agricultural technology public goods, older farmers are more concerned about public safety and old age security products.

(3) Respondent's years of education. Farmers with more education have higher requirements for the quality of public goods. Therefore, the length of education of farmers is likely to affect their overall evaluation of rural public goods.

(4) Farmers' income per capita. To a certain extent, the increase in the supply of some rural public goods will increase the income level of farmers. Therefore, imbalance in the provision of public goods across different regions will inevitably lead to imbalance in the income levels of the farmers in the different regions. This will lead to differences in the level of satisfaction with the supply of public goods in different regions. Therefore, this paper chooses the income per capita of farmers as the independent variable to examine its impact on the satisfaction of farmers' public goods supply.

(5) Respondent's involvement with agriculture. Under normal circumstances, people employed in agriculture are more concerned about the provision of public goods such as farmland water conservancy facilities and agricultural services than those who are not. At the same time, those engaged in agriculture pay more attention to the supply of rural public goods because they have lived in rural areas for a long time.

(6) Whether the respondent's village is in a mountainous area. Farmers under different geographical conditions have different needs and preferences for public goods. Farmers in mountainous areas are more likely to be satisfied with the supply of public goods.

(7) Time the respondent has lived at home. Those who live at home for longer periods pay more attention to the supply of public goods than those who do not live at home, because they have tangible needs.

(8) Financial transparency of the provision of public goods. Financial transparency involves farmers' level of understanding and trust in the process of providing public goods. When farmers are clearer about the provision of public goods, their trust in the government increases, ultimately improving their satisfaction. 
(9) Whether the respondent needs to share the costs. If the provision of public goods requires farmers to share the costs, their satisfaction will be reduced, since such costs indirectly reduce their disposable income.

(10) Whether farmers' opinions are solicited in the process of supplying public goods. The solicitation of opinions indicates democracy in the process of supplying public goods. A democratic government will increase farmers' satisfaction with the supply of public goods.

(11) Whether the farmers profit from the supply of public goods. If farmers can gain tangible benefits from the supply of public goods, such as improving their living standards or increasing their income, their satisfaction will increase.

We use the variable Gender to represent the gender of the farmers, Age to represent their age, Education to represent their years of education, Income to represent their income per capita, Agriculture to represent whether the respondent is engaged in agriculture, Mountain to represent whether the respondent's village is in a mountainous area, Home to represent time when the respondent has lived at home, Finance to represent financial transparency in the provision of public goods, Cost to represent whether the respondent needs to share the cost, Opinion to represent whether farmers' opinions are solicited in the process of supplying public goods, and Benefit to represent whether the farmers profit from the supply of public goods.

Table 1 shows the definitions and illustrations of the variables. We can see that all the dependent variables are ordered variables. The explanatory variables Gender, Age, Education, Income, Agriculture, and Home all indicate characteristics of the respondents; Agriculture represents the geographical characteristics of the area in which the respondents are located; and Finance, Cost, Opinion, and Benefit refer to explanatory variables related to the supply of public goods.

\section{Table 1. \\ Definitions and Illustrations of Variables}

Table 1 shows the definitions and illustrations of variables. Column 1 contains all the variables, we can see that all the dependent variables are ordered variables. Contain 2 contains the definition of the variables. Column 3 contains the valuation of all the variables.

\begin{tabular}{llc}
\hline Variable & \multicolumn{1}{c}{ Definition } & Valuation \\
\hline FWCF & Farmland water conservancy facility & \\
CR & Country road & $1=$ Very not satisfied; \\
AS & Agricultural services & $2=$ Not satisfied; \\
MH & Medical hygiene & $3=$ Indifferent; \\
CE & Compulsory education & $4=$ Satisfied; \\
DWF & Drinking water facility & $5=$ Very satisfied. \\
ICT & Information and communications technology & \\
GD & Garbage disposal. & \\
\hline
\end{tabular}


Table 1.

Definitions and Illustrations of Variables (cont.)

Table 1 shows the definitions and illustrations of variables. Column 1 contains all the variables, we can see that all the dependent variables are ordered variables. Contain 2 contains the definition of the variables. Column 3 contains the valuation of all the variables.

\begin{tabular}{|c|c|c|}
\hline Variable & Definition & Valuation \\
\hline Gender & The gender of farmers & 1=Man; 0=Woman \\
\hline Age & The age of farmers & $18-70$ \\
\hline Education & The years of education of farmers & Year (s) \\
\hline Income & The income per capita of farmers & $\begin{array}{c}<8000 \text { yuan }=1 ; 8000-15000 \text { yuan=2; } \\
15000-20000 \text { yuan=3; } \\
>=20000 \text { yuan }=4\end{array}$ \\
\hline Agriculture & Whether the respondent is engaged in agriculture & $1=\mathrm{Yes} ; 0=\mathrm{No}$ \\
\hline Mountain & $\begin{array}{l}\text { Whether the village where the respondent is } \\
\text { located in the mountainous area }\end{array}$ & $1=$ Yes; $0=\mathrm{No}$ \\
\hline Home & Time when the respondent lived at home & $\begin{array}{c}<3 \text { months }=1 ; 3-6 \text { months }=2 ; 6-9 \\
\text { months }=3 ; 9-12 \text { months }=4\end{array}$ \\
\hline Finance & $\begin{array}{l}\text { Financial transparency when providing public } \\
\text { goods }\end{array}$ & $1=$ Yes; $0=\mathrm{No}$ \\
\hline Cost & Whether the respondent needs to share the cost & $1=$ Yes; $0=\mathrm{No}$ \\
\hline Opinion & $\begin{array}{l}\text { Whether to solicit opinions from farmers in the } \\
\text { process of supplying public goods }\end{array}$ & $1=\mathrm{Yes} ; 0=\mathrm{No}$ \\
\hline Benefit & $\begin{array}{l}\text { Whether the farmers profit from public goods } \\
\text { supply }\end{array}$ & $1=$ Yes; $0=\mathrm{No}$ \\
\hline
\end{tabular}

Table 2 shows the descriptive statistics for the dependent and explanatory variables. Among all public goods, farmers are most satisfied with health care and the least satisfied with compulsory education. The mean value of Gender is 0.503, which means that the gender ratio of the respondents is very low. The mean of Age is 41.475 and the standard deviation is 9.533, indicating that mostly of the respondents are middle-aged. The mean of Education is 7.52, which means that the educational level of the rural population is still low in China. A total of $47 \%$ of the respondents are located in mountainous areas, suggesting that the geographical environment is relatively harsh in western China. The mean of Finance is 0.615 , meaning that $61.5 \%$ of the respondents believe that government finance is open and transparent in the process of supplying public goods. The mean of Cost is 0.473 , indicating that about $47.3 \%$ of respondents undertake costs in the public goods supply process. The mean of Opinion is 0.623 , indicating that $62.3 \%$ of the respondents believe the government solicits their opinions before supplying public goods. The mean of Benefit is 0.48 , which means that $48 \%$ of respondents feel they have benefited from the government's supply of public goods. 
Table 2.

\section{Descriptive Statistics of Variables in the Model}

This table presents the descriptive statistics for data. Column 2 contains the number of observations (Obs.) in the sample. The mean, standard deviation (SD), and the minimum (Min.) and maximum (Max.) values are presented in Columns 3 to 6 , respectively.

\begin{tabular}{lccccc}
\hline Variable & Observations & Mean & SD & Min. & Max. \\
\hline FWCF & 400 & 2.923 & 1.095 & 1 & 5 \\
$C R$ & 400 & 2.883 & 1.042 & 1 & 5 \\
AS & 400 & 3.125 & 1.106 & 1 & 5 \\
MH & 400 & 3.223 & 1.160 & 1 & 5 \\
$C E$ & 400 & 2.798 & 1.162 & 1 & 5 \\
DWF & 400 & 2.97 & 1.110 & 1 & 5 \\
ICT & 400 & 2.915 & 1.123 & 1 & 5 \\
GD & 400 & 2.898 & 1.160 & 1 & 5 \\
\hline Gender & 400 & 0.503 & 0.501 & 0 & 1 \\
Age & 400 & 41.475 & 9.533 & 18 & 70 \\
Education & 400 & 7.52 & 2.797 & 1 & 16 \\
Income & 400 & 2.943 & 1.038 & 1 & 5 \\
Agriculture & 400 & 0.878 & 0.328 & 0 & 1 \\
Mountain & 400 & 0.47 & 0.500 & 0 & 1 \\
Home & 400 & 2.563 & 1.095 & 1 & 4 \\
Finance & 400 & 0.615 & 0.487 & 0 & 1 \\
Cost & 400 & 0.473 & 0.500 & 0 & 1 \\
Opinion & 400 & 0.623 & 0.485 & 0 & 1 \\
Benefit & 400 & 0.48 & 0.500 & 0 & 1 \\
\hline
\end{tabular}

\section{B. Methodology}

The literature on the satisfaction of rural public goods supply is based on binary models, such as the binary logit or binary probit model, which cannot reflect the degrees of farmers' satisfaction. The binary model is limited in that there are only two values for the dependent variable (satisfied $=1$, dissatisfied $=0$ ), which cannot reflect the level of the farmers' evaluation. Having obtained sufficient numbers of samples, this paper attempts to further refine the evaluation of rural public goods and deeply explore the influencing factors behind it to propose more relevant recommendations in the supply of rural public goods. Therefore, this paper uses ordinal logit and ordinal probit models to analyze the factors influencing farmers' satisfaction. There is no essential difference between the logit and probit models and, generally, they can be used interchangeably. However, the distribution functions they use are different. Since the distribution of random variables is difficult to determine in advance, the model residuals can obey either a standard normal distribution or a logistic distribution. Therefore, to make the regression results more accurate, probit and logit regressions are performed for mutual corroboration purposes. 
We use $Y^{*}$ to denote the satisfaction of farmers, functionally related with its influencing factors as follows:

$$
Y^{*}=X \beta+\varepsilon, \varepsilon \sim N(0, \sigma)
$$

where $X$ is the influencing factors, $\beta$ is a parameter vector, and $\varepsilon$ obeys a normal distribution with mean zero. We define $Y$ as follows:

$$
Y=\left\{\begin{array}{l}
1, \text { if } Y \leq \delta_{1} \\
2, \text { if } \delta_{1}<Y \leq \delta_{2} \\
3, \text { if } \delta_{2}<Y \leq \delta_{3} \\
4, \text { if } \delta_{3}<Y \leq \delta_{4} \\
5, \text { if } \delta_{4}<Y \leq \delta_{5}
\end{array}\right.
$$

where $Y=1,2, \ldots, 5$ represent the responses "very dissatisfied," "dissatisfied," "indifferent," "satisfied," and "very satisfied," respectively, and, $\delta_{1}, \delta_{2}, \delta_{3^{\prime}} \delta_{4}$ and $\delta_{5}$ are critical points. For the logit distribution hypothesis, the random variable is as follows:

$$
\operatorname{Pr}\left(Y^{*}<x\right)=\Lambda(x)=1 /\left(1+\exp ^{(-x)}\right)
$$

For the standard normal distribution (probit) hypothesis,

$$
\operatorname{Pr}\left(Y^{*}<x\right)=\Phi(x)=\int_{0}^{x}(1 / 2 \pi) \exp \left(-x^{2} / 2\right) d x
$$

This paper gives two estimates, which is useful for comparing the stability of the coefficients of the different distribution hypotheses.

\section{EMPIRICAL RESULTS}

This paper aims to investigate farmers' satisfaction with the supply of public goods and the influencing factors. Before the results for the regression model, we list the correlation coefficients between the explanatory variables. Table 3 shows there is no strong correlation between the indicators of each variable, so it is suitable to continue the regression analysis. Tables 4 and 5 list the regression results for the ordered logit and ordered probit models, respectively. 
Table 3.

The Correlation Coefficient Matrix Between Independent Variables

This table presents the correlation coefficient matrix between variables.

\begin{tabular}{lcccccccccc}
\hline & Gender & Age & Education & Income & Agriculture & Mountain & Home & Finance & Cost & Opinion Benefit \\
\hline Gender & 1.000 & & & & & & & & & \\
Age & -0.019 & 1.000 & & & & & & & & \\
Education & -0.112 & -0.116 & 1.000 & & & & & & & \\
Income & -0.002 & 0.018 & 0.397 & 1.000 & & & & & & \\
Agriculture & -0.020 & -0.059 & -0.180 & -0.503 & 1.000 & & & & & \\
Mountain & 0.015 & -0.000 & -0.061 & -0.576 & 0.361 & 1.000 & & & & \\
Home & -0.000 & 0.016 & -0.003 & 0.040 & 0.034 & -0.091 & 1.000 & & & \\
Finance & -0.006 & -0.030 & 0.006 & 0.001 & 0.020 & 0.004 & 0.031 & 1.000 & & \\
Cost & 0.010 & 0.075 & -0.235 & -0.266 & 0.337 & -0.018 & 0.044 & -0.033 & 1.000 & \\
Opinion & -0.032 & -0.021 & -0.258 & -0.620 & 0.390 & 0.372 & -0.024 & -0.023 & 0.055 & 1.000 \\
Benefit & -0.005 & 0.073 & -0.222 & -0.265 & 0.323 & -0.033 & 0.046 & -0.021 & 0.945 & 0.057 \\
\hline
\end{tabular}

Table 4.

\section{Estimation Results of the Ordinal Logistic Model}

This table shows the estimation results of the ordinal logistic model. The values in parentheses denote the standard errors. " $* *$ indicates significance at the $10 \%$ level; ${ }^{\prime * * * \prime}$ indicates significance at the $5 \%$ level; ${ }^{\prime * * * * \prime}$ indicates significance at the $1 \%$ level.

\begin{tabular}{|c|c|c|c|c|c|c|c|c|}
\hline Variables & $\begin{array}{c}\text { FWCF } \\
\text { (1) }\end{array}$ & $\begin{array}{l}\text { CR } \\
(2) \\
\end{array}$ & $\begin{array}{l}\text { AS } \\
(3)\end{array}$ & $\begin{array}{c}\text { MH } \\
\text { (4) }\end{array}$ & $\begin{array}{l}\text { CE } \\
(5)\end{array}$ & $\begin{array}{c}\text { DWF } \\
(6)\end{array}$ & $\begin{array}{c}\text { ICT } \\
(7) \\
\end{array}$ & $\begin{array}{c}\text { GD } \\
(8)\end{array}$ \\
\hline \multirow[t]{2}{*}{ Gender } & -0.109 & -0.006 & 0.204 & -0.022 & -0.118 & 0.015 & -0.076 & -0.127 \\
\hline & {$[0.364]$} & {$[0.223]$} & {$[0.228]$} & {$[0.184]$} & [0.199] & [0.155] & [0.115] & [0.113] \\
\hline \multirow[t]{2}{*}{ Age } & -0.004 & -0.017 & -0.020 & $0.018^{*}$ & $-0.023^{* *}$ & -0.005 & $-0.013^{* *}$ & 0.000 \\
\hline & [0.016] & 0.012 & {$[0.013]$} & {$[0.010]$} & {$[0.011]$} & [0.008] & {$[0.006]$} & {$[0.006]$} \\
\hline \multirow[t]{2}{*}{ Education } & -0.020 & 0.005 & 0.032 & 0.014 & $-0.262^{* * *}$ & 0.010 & $-0.238^{* * *}$ & $-0.061^{* * *}$ \\
\hline & [0.059] & 0.047 & {$[0.053]$} & [0.039] & {$[0.049]$} & {$[0.030]$} & {$[0.025]$} & 0.023 \\
\hline \multirow[t]{2}{*}{ Income } & $-12.022^{* * *}$ & $-3.344^{* * *}$ & $-3.433^{* * *}$ & $-1.065^{* * *}$ & $-2.198^{* * *}$ & $-3.947^{* * *}$ & $-1.014^{* * *}$ & $-1.243^{* * *}$ \\
\hline & [1.437] & {$[0.260]$} & {$[0.285]$} & {$[0.158]$} & {$[0.214]$} & {$[0.298]$} & {$[0.100]$} & [0.104] \\
\hline \multirow[t]{2}{*}{ Agriculture } & -0.068 & -0.235 & $-0.517^{* * *}$ & 0.138 & 0.104 & 0.030 & -0.060 & 0.110 \\
\hline & [0.649] & {$[0.270]$} & {$[0.476]$} & [0.233] & [0.242] & [0.199] & [0.140] & [0.136] \\
\hline \multirow[t]{2}{*}{ Mountain } & $1.165^{* *}$ & 0.407 & $0.689^{* *}$ & 0.311 & 0.208 & -0.234 & $0.253^{*}$ & $-0.272^{*}$ \\
\hline & {$[0.481]$} & [0.303] & {$[0.286]$} & {$[0.240]$} & {$[0.271]$} & {$[0.210]$} & [0.152] & [0.147] \\
\hline \multirow[t]{2}{*}{ Home } & 0.146 & 0.114 & 0.055 & -0.014 & $0.159^{*}$ & 0.008 & 0.052 & 0.025 \\
\hline & [0.165] & {$[0.101]$} & [0.104] & {$[0.084]$} & [0.091] & {$[0.071]$} & [0.052] & {$[0.051]$} \\
\hline \multirow[t]{2}{*}{ Finance } & 0.235 & 0.086 & 0.123 & 0.204 & -0.044 & -0.012 & 0.022 & 0.080 \\
\hline & {$[0.364]$} & {$[0.227]$} & [0.233] & [0.188] & [0.203] & [0.158] & {$[0.117]$} & [0.115] \\
\hline \multirow[t]{2}{*}{ Cost } & -0.340 & -0.018 & -0.899 & -0.257 & -0.656 & -0.318 & $-0.959 * *$ & 0.216 \\
\hline & [1.025] & {$[0.651]$} & [0.694] & {$[0.579]$} & {$[0.603]$} & {$[0.417]$} & {$[0.366]$} & [0.343] \\
\hline \multirow[t]{2}{*}{ Opinion } & $2.950^{* * *}$ & $0.834^{* * *}$ & 0.025 & $0.637^{* * *}$ & $0.420^{*}$ & $0.934^{* * *}$ & $0.354^{* *}$ & $0.257^{*}$ \\
\hline & {$[0.692]$} & [0.295] & {$[0.401]$} & {$[0.247]$} & [0.255] & {$[0.216]$} & {$[0.153]$} & [0.148] \\
\hline \multirow[t]{2}{*}{ Benefit } & $4.190^{* * *}$ & 0.638 & $2.078^{* * *}$ & $1.190^{* *}$ & $1.236^{* *}$ & $1.481^{* * * *}$ & $0.857^{* *}$ & 0.058 \\
\hline & [1.100] & [0.649] & {$[0.712]$} & {$[0.576]$} & [0.597] & {$[0.434]$} & {$[0.363]$} & {$[0.340]$} \\
\hline$N$ & 400 & 400 & 400 & 400 & 400 & 400 & 400 & 400 \\
\hline Pseudo $R^{2}$ & 0.857 & 0.508 & 0.478 & 0.125 & 0.380 & 0.747 & 0.443 & 0.400 \\
\hline Pro $>C h i^{2}$ & 0.000 & 0.000 & 0.000 & 0.000 & 0.000 & 0.000 & 0.000 & 0.000 \\
\hline$L R C h i^{2}$ & 1014.22 & 584.27 & 438.54 & 149.42 & 457.89 & 887.50 & 530.42 & 482.18 \\
\hline
\end{tabular}


Table 5.

Estimation Results of the Ordinal Probit Model

This table shows the estimation results of the ordinal probit model. The values in parentheses denote the standard errors. " ${ }^{* *}$ indicates significance at the $10 \%$ level; ${ }^{a * * \prime \prime}$ indicates significance at the $5 \%$ level; ${ }^{\prime * * * *}$ indicates significance at the $1 \%$ level.

\begin{tabular}{|c|c|c|c|c|c|c|c|c|}
\hline Variables & $\begin{array}{c}\text { FWCF } \\
\text { (1) }\end{array}$ & $\begin{array}{l}\text { CR } \\
\text { (2) }\end{array}$ & $\begin{array}{l}\text { AS } \\
\text { (3) }\end{array}$ & $\begin{array}{c}\text { MH } \\
\text { (4) }\end{array}$ & $\begin{array}{l}C E \\
\text { (5) }\end{array}$ & $\begin{array}{c}\text { DWF } \\
\text { (6) }\end{array}$ & $\begin{array}{c}\text { ICT } \\
(7)\end{array}$ & $\begin{array}{l}\text { GD } \\
(8)\end{array}$ \\
\hline \multirow[t]{2}{*}{ Gender } & -0.243 & -0.011 & 0.105 & -0.060 & -0.078 & 0.089 & -0.130 & -0.142 \\
\hline & {$[0.180]$} & [0.119] & [0.124] & [0.108] & [0.113] & [0.292] & {$[0.210]$} & [0.204] \\
\hline \multirow[t]{2}{*}{ Age } & -0.008 & -0.010 & $-0.012^{*}$ & 0.009 & $-0.014^{* *}$ & -0.008 & $-0.020^{*}$ & -0.002 \\
\hline & [0.008] & 0.006 & [0.007] & [0.006] & {$[0.006]$} & [0.015] & {$[0.011]$} & [0.011] \\
\hline \multirow[t]{2}{*}{ Education } & $-0.060^{*}$ & 0.001 & 0.008 & -0.004 & $-0.185^{* * *}$ & 0.021 & $-0.301^{* * *}$ & -0.041 \\
\hline & {$[0.031]$} & 0.024 & {$[0.027]$} & {$[0.023]$} & {$[0.025]$} & {$[0.052]$} & {$[0.054]$} & 0.043 \\
\hline \multirow[t]{2}{*}{ Income } & $-4.614^{* * *}$ & $-1.519^{* * *}$ & $-1.732^{* * *}$ & $-0.526^{* * *}$ & $-0.925^{* * *}$ & $-8.241^{* * *}$ & $-2.663^{* * *}$ & $-2.932^{* * *}$ \\
\hline & {$[0.402]$} & {$[0.114]$} & {$[0.136]$} & {$[0.089]$} & {$[0.097]$} & {$[0.782]$} & {$[0.237]$} & {$[0.233]$} \\
\hline \multirow[t]{2}{*}{ Agriculture } & 0.092 & -0.142 & -0.374 & 0.080 & 0.207 & 0.009 & -0.162 & -0.009 \\
\hline & {$[0.264]$} & [0.146] & {$[0.255]$} & [0.131] & {$[0.137]$} & [0.407] & {$[0.250]$} & {$[0.248]$} \\
\hline \multirow[t]{2}{*}{ Mountain } & $0.594^{* *}$ & 0.237 & 0.237 & 0.161 & 0.089 & -0.183 & 0.411 & -0.401 \\
\hline & [0.259] & [0.155] & [0.159] & [0.139] & [0.147] & [0.377] & [0.298] & [0.275] \\
\hline \multirow[t]{2}{*}{ Home } & 0.081 & 0.082 & 0.032 & -0.016 & $0.108^{* *}$ & 0.083 & 0.081 & 0.058 \\
\hline & {$[0.081]$} & {$[0.054]$} & {$[0.057]$} & [0.049] & {$[0.051]$} & [0.135] & [0.097] & [0.092] \\
\hline \multirow[t]{2}{*}{ Finance } & 0.017 & 0.104 & 0.073 & 0.149 & -0.042 & 0.074 & 0.057 & 0.165 \\
\hline & {$[0.180]$} & [0.121] & {$[0.127]$} & [0.110] & [0.115] & [0.298] & {$[0.214]$} & {$[0.207]$} \\
\hline \multirow[t]{2}{*}{ Cost } & 0.496 & 0.023 & -0.442 & -0.120 & -0.472 & -0.432 & $-1.369^{* *}$ & -0.203 \\
\hline & [0.424] & {$[0.360]$} & [0.379] & {$[0.333]$} & {$[0.361]$} & {$[0.770]$} & {$[0.630]$} & [0.609] \\
\hline \multirow[t]{2}{*}{ Opinion } & $1.065^{* * *}$ & $0.474^{* * *}$ & 0.034 & $-0.356^{* *}$ & 0.141 & $1.978^{* * *}$ & $0.589^{* * *}$ & $0.613^{* *}$ \\
\hline & {$[0.271]$} & {$[0.162]$} & {$[0.220]$} & {$[0.143]$} & [0.149] & {$[0.431]$} & {$[0.275]$} & {$[0.264]$} \\
\hline \multirow[t]{2}{*}{ Benefit } & $0.921^{* *}$ & 0.152 & $0.941^{* *}$ & $0.645^{*}$ & $0.775^{* *}$ & $3.189^{* * *}$ & $1.558^{* *}$ & 0.770 \\
\hline & {$[0.411]$} & [0.358] & [0.379] & [0.332] & {$[0.358]$} & {$[0.840]$} & {$[0.624]$} & {$[0.607]$} \\
\hline$N$ & 400 & 400 & 400 & 400 & 400 & 400 & 400 & 400 \\
\hline Pseudo $R^{2}$ & 0.804 & 0.465 & 0.456 & 0.107 & 0.334 & 0.740 & 0.383 & 0.327 \\
\hline Pro $>C h i^{2}$ & 0.000 & 0.000 & 0.000 & 0.000 & 0.000 & 0.000 & 0.000 & 0.000 \\
\hline LR Chi $i^{2}$ & 952.14 & 535.31 & 514.18 & 128.75 & 403.33 & 879.37 & 459.12 & 394.79 \\
\hline
\end{tabular}

The empirical results show that the coefficient of the variable Income is significantly negative in all models, indicating that the income of farmers has a significant impact on their satisfaction in eight categories of public goods supply, at the $1 \%$ level. The main reason for this finding is that the higher the income of farmers, the higher the demand for public goods. At present, the provision of rural public goods can only meet the basic production and living needs of farmers and not their higher needs. Therefore, the higher the income of farmers, the less likely their needs are being met, significantly reducing their satisfaction.

In most models, the coefficient of Opinion is significantly positive at the $10 \%$ level, which means that farmers who have been consulted in the process of the supply of public goods are more satisfied than farmers who have not. On the one hand, the government's request for the public's opinions in the implementation of a public decision is a manifestation of democracy. Compared to nondemocratic 
governments, people are more satisfied with democratic governments. On the other hand, the purpose of the government's consultation with farmers is to meet their needs as much as possible. Therefore, compared to farmers not consulted in the process of the supply of public goods, those who are consulted experience higher levels of satisfaction.

In most models, the coefficient of Benefit is significantly positive at the $5 \%$ level, indicating that, compared to farmers who do not profit from the supply of public goods, those who do profit are more satisfied. The main reason for this is that farmers' production and life are more convenient when public products are available. Another reason could be that their material and spiritual needs have been met to some extent because of the supply of public goods.

Specifically, the coefficient of the variable Mountain is significantly negative at the 5\% level in column (1) of Tables 4 and 5, indicating that farmers located in mountainous areas are not more satisfied with the supply of Farmland Water Conservancy Facilities (FWCF) than those who are not located in mountainous areas. The main reason for this is that, in recent years, to develop mountainous agriculture, government increased the construction of farmland water conservancy in mountainous areas and various sprinkler irrigation and irrigation canal renovation projects have been carried out in full swing, achieving remarkable economic benefits.

The coefficient of Agriculture is significant and negative at the 1\% level in column (3) in Tables 4 and 5, which means that the respondents who are engaged in agriculture are less satisfied with the supply of Agricultural Services $(A S)$. Public goods in agricultural services mainly include agricultural technology services, agricultural machinery promotion, and pest control. Compared to respondents not engaged in agriculture, those who are have greater demand for agricultural services. However, the government's supply of agricultural services cannot effectively meet the needs of farmers.

The coefficient of Age is significant and positive at the $10 \%$ level in column (4), which reveals that the older the respondents, the greater their satisfaction with Medical Hygiene services $(M H)$. The main reason for this is that, in recent years, the government has introduced many medical insurance policies to enable the rural elderly to receive adequate medical services. Precise poverty alleviation policies have also alleviated the disparity between the low economic income of the elderly and their high medical demand.

The coefficient of Education is significantly negative at the 1\% level in column (5), indicating that higher education levels of the respondents reduces their satisfaction with Compulsory Education (CE). The reason for this result could be that the higher the education levels of the respondents, the greater their demands for quality in compulsory education in the village. At present, the quality of compulsory education in rural China, especially in the western rural areas, is relatively low and the ability of teachers is limited, conditions that cannot meet the needs of some respondents.

The coefficient of the Cost variable is significantly negative at the $5 \%$ level in column (7), indicating that the respondents who need to bear the costs for the provision of ICT are less satisfied than those who do not. Such costs mean 
a reduction in the disposable income of farmers to a certain extent, which can reduce their satisfaction. This result also means that, if the cost of rural public goods supply is borne by the farmers, the farmers could be induced to choose more private products and ignore public goods, which will further lead to inadequate rural public goods.

The coefficient of the variable Education is significantly negative at the 5\% level in column (8), indicating that the increase in the number of years of education of the respondents reduces their satisfactory with Garbage Disposal services (GD). This result also shows that farmers do not want to pay for garbage disposal in rural areas.

The other variables have no impact on farmers' satisfaction among the eight categories of public goods supply.

\section{CONCLUSION AND POLICY IMPLICATIONS}

Using cross-sectional data on 400 farmers in five counties of China's Shaanxi province, this study adopts ordinal logit and probit models to investigate rural residents' satisfaction with the supply of public goods and influencing factors. The empirical results indicate that the income of farmers (Income), whether their opinions are solicited in the process of public goods supply (Opinion), and whether the farmers profit from the supply of public goods (Benefit) are the main influencing factors in the farmers' evaluation of their satisfaction with rural public goods. These three variables affect farmers' satisfaction in almost of the eight categories of public goods supply. Additionally, the variables Age, Education, Agriculture, Cost, and Mountain have a significant impact on the satisfaction of some public products. For example, the older the respondents, the greater their satisfaction with medical hygiene services and higher levels of education among the respondents reduces their satisfaction with Compulsory Education (CE).

The satisfaction of farmers in the supply of rural public goods is also an important indicator of the effectiveness of rural public goods investment. The government needs to bear certain responsibilities in the improvement of farmers' satisfaction levels. To improve the satisfaction of farmers and the efficiency of public goods supply, the government should adopt the following measures.

First, the government should enhance the democratic nature of public decision making. This would mean that, when making public decisions, the government should ask the opinions of the farmers and respect the will of the public. A supply decision making mechanism should be established and/or improved, so that the supply and demand of rural public goods becomes consistent, the government's supply efficiency is improved, and blind supply is eliminated.

Second, the government's inclination to supply rural public goods should be increased. The provision of public goods requires not only the government's support but also the help of the farmers themselves. However, given farmers' low income and education levels, the government should effectively adopt a specialized financial system to promote new construction in the countryside. In areas with poor economic conditions, it is best for the government to pay for all public goods. 
Third, the government should implement different countermeasures according to each village's specific conditions. Farmers at different economic development levels and with different geographical characteristics have different needs for public goods. Therefore, the government cannot adopt a unified standard for the supply of rural public goods.

\section{REFERENCES}

Cardozo, R. N. (1965). An Experimental Study of Customer Effort, Expectation, and Satisfaction. Journal of Marketing Research, 2, 244-249.

Fan, L. M., Xie, E., \& Shi, S. B. (2008). Research on the Balance of Supply and Demand of Rural Public Goods Based on Farmers' Perspective (in Chinese). Contemporary Economic Science, 30, 56-64.

Fornell, C. (1992). A National Customer Satisfaction Barometer: The Swedish Experience. Journal of Marketing, 56, 6-21.

Gu, H. B., \& W, J. J. (2005). Efficiency Analysis and Mode Selection of Rural Public Goods Supply System (in Chinese). Commercial Research, 61, 33-36.

$\mathrm{Hsu}$, S. H. (2008). Developing an Index for Online Customer Satisfaction: Adaptation of American Customer Satisfaction Index. Journal of Expert System with Applications, 34, 3033-3042.

Ju, Q. J., \& Pang, M. (2005). Analysis of the Mechanism of Infrastructure's Effect on Rural Economic Development (in Chinese). Economic System Reform, 36, 89-92.

Li, Q., Luo, R. F., Liu, C. F., \& Zhang, L. X. (2006). What Kind of Public Services are Most Needed by Farmers in the Construction of New CountrysideAnalysis of Farmers' Willingness to Invest in Rural Public Goods (in Chinese). Agricultural Economic Problems, 39, 15-20.

Li, W., Yan, X. C., \& Hua, F. F. (2014). Research on Rural Public Goods Demand Satisfaction Based on Factor Analysis (in Chinese). Statistics and Information Forum, 29, 78-84.

Li, Y. L. (2008). Empirical Study on the Efficiency of Rural Public Goods Supply (in Chinese). Journal of Public Administration, 16, 14-23.

Li, Y. L., \& Zeng, F. S. (2008). The Analysis of Farmers' Satisfaction Index to Rural Public Goods Supply and It's Influencing Factors (in Chinese). Quantitative Economics and Economics Research, 35, 3-18.

Wang, L., \& Zhu, Y. C. (2012). Evaluation of Rural Public Goods Supply Based on Farmers' Perspective (in Chinese). Journal of Northwest AEF University (Social Science Edition), 12, 24-29.

Wang, Q. (2008). Analysis of the Satisfaction and Demand Level of Rural Public Service Supply Based on Farmers' View - Taking the Investigation of Three Counties in Shandong Province as an Example (in Chinese). Shandong Social Sciences, 32, 152-155.

Wang, X. L., \& Jiang, J. Y. (2009). An Empirical Study on the Satisfaction of Rural Public Goods to Farmers-Taking Zhejiang Province as an Example (in Chinese). Economic Research Guide, 14, 44-46.

Wang, Y. Z., \& Jiang, C. P. (2010). Analysis of Factors Affecting the Satisfaction of Rural Residents (in Chinese). Chinese Rural Economy, 34, 80-87. 
Xiao, L. (2012). Analysis and Evaluation of Rural Public Goods Supply Farmers' Satisfaction (in Chinese). Agricultural Technology Economy, 37, 71-76.

Xu, D. D., Xie, F. T., \& Liu, S. Q. (2014). Farmers' Satisfaction with the Supply of Irrigation Facilities in Mountainous Areas and Its Influencing Factors: A Case Study of 402 Farmers in Sichuan Province (in Chinese). Journal of China Agricultural University, 19, 218-226.

Xu, L. (2012). Empirical Analysis of Farmers' Satisfaction with Rural Public Goods Supply-Based on Field Survey of Farmers in Jiangxi Province (in Chinese). Statistics and Information Forum, 27, 102-108.

Zeng, L. (2008). The Government's Supply of Rural Public Goods and Their Behavior Choice (in Chinese). Rural Economy, 38, 13-15.

Zhao, Y., \& Jiang, H. C. (2007). The Supply Situation of Major Rural Public Goods Based on Farmers' Perspective: A Case Study of 32 Administrative Villages in 11 Counties (cities) of Shandong Province (in Chinese). Chinese Rural Economy, 34, 52-62.

Zheng, W. R. (2011). Analysis on Satisfaction of Rural Public Service and its Countermeasures - A Case Study in Zhejiang Province (in Chinese). Journal of Huazhong Agricultural University (Social Sciences Edition), 63, 74-81.

Zhu, Y. C. \& Tang, L. J. (2010). Analysis of Factors Affecting Rural Public Goods Investment Satisfaction-Based on Survey of Farmers in Five Northwest Provinces (in Chinese). Journal of Public Administration, 16, 31-38.

Zhu, Y. C., Tang, L. J., \& Luo, D. (2011). Evaluation of Rural Public Goods Supply Effect: Response from Farmers' Income Gap (in Chinese). Management World, $32,74-80$. 
This page is intentionally left blank 